\title{
Some factors influencing the effect of cholesterol on streptolysin $\mathrm{O}$ activity
}

\author{
K. C. WATSON, T. P. ROSE, AND E. J. C. KERR \\ From the Central Microbiological Laboratories, Western General Hospital, Edinburgh
}

SYNOPSIS Inhibition of streptolysin $\mathrm{O}$ activity by cholesterol depends on the latter being in free form. The normal esterified and protein-bound cholesterol fractions in serum do not influence streptolysin $\mathrm{O}$ activity. However, high cholesterol levels in rabbits fed cholesterol with cholic acid were associated with an increased antistreptolysin $\mathrm{O}$ effect. It is suggested that this occurs when all available protein sites are saturated and where a true 'free' cholesterol fraction is present.

Splitting the esterified cholesterol fraction of human sera with raised cholesterol levels, by means of pancreatin, produced an increased antistreptolysin $\mathrm{O}$ effect, again presumably because of saturation of protein-binding sites. Similarly, removal of non-esterified cholesterol from sera of cholesterolfed rabbits, by means of digitonin, reduced antistreptolysin $\mathrm{O}$ activity of the sera.

Evidence is presented that combination of bovine serum albumin and streptolysin $\mathrm{O}$ has a steric hindrance effect on attachment of cholesterol to streptolysin $O$.

The method described for the estimation of free cholesterol is extremely sensitive, being capable of detecting concentrations of less than $1.0 \mu \mathrm{g} / \mathrm{ml}$.

Confirmation of group A streptococcal infection by estimation of antistreptolysin activity remains one of the most useful of serological tests in terms of reproducibility, clarity of end-point, high percentage of positive results, and relative absence of nonspecific reactions. Non-specific positive reactions are known to be obtained with sera contaminated with bacteria. Strains of the genus Pseudomonas appear to be especially involved (Watson, Rose, and Kerr, 1971). Additionally it is known that cholesterol can inhibit reduced streptolysin ' $O$ ' (SLO) activity (Hewitt and Todd, 1939). The mechanism of the latter has been studied by Alouf and Raynaud (1968), who have shown that cholesterol acts by combining with the reduced SLO and prevents its attachment to cell membranes. Haemolysis by saponins is also inhibited by cholesterol but the mechanism of action appears different.

The present investigation was undertaken to determine the effect of variations in serum cholesterol levels on streptolysin $O$ activity and also some of the factors influencing cholesterol inhibition of streptolysin $\mathbf{O}$.

Received for publication 17 August 1972.

\section{Materials and Methods}

ANTISTREPTOLYSIN ESTIMATIONS

These were done by the standard method of Rantz and Randall (1945). Briefly, heat inactivated serum ( $56^{\circ}$ for 30 minutes) is diluted in phosphate-buffered saline $(p H$ 6.7) from three master dilutions $(1 / 10$, $1 / 100$, and $1 / 500$ ). To each $1.0 \mathrm{ml}$ volume of serum dilution in 3 in. $\times \frac{1}{2}$ in. tubes is added $0.5 \mathrm{ml}$ of reduced streptolysin $O$ (containing $1.0 \mathrm{IU}$ ). Tubes are incubated at $37^{\circ}$ for 15 minutes followed by the addition of $0.5 \mathrm{ml}$ of a $5.0 \%$ suspension of washed human red cells. Tubes are then reincubated for a further 45 minutes at $37^{\circ}$. After centrifugation of the tubes the percentage haemolysis in the supernatant is estimated visually. Suitable streptolysin $O$ and standard antistreptolysin serum controls are included. The $50 \%$ haemolytic end points are expressed as Todd units, representing the reciprocals of the serum dilutions.

CHOLESTEROL SUSPENSIONS

Pure cholesterol powder was dissolved in absolute ethanol at $1.0 \%$ concentration. Further dilutions 
were then made in antistreptolysin $O$ phosphate

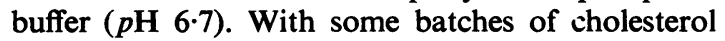
this procedure resulted in a stable colloidal suspension presenting maximum surface area of cholesterol to the streptolysin $\mathrm{O}$. However, with some batches dilution in buffer produced a floccular precipitate with much reduced activity on streptolysin $O$. In this instance stable colloidal suspensions were obtained by the addition of $0.01 \mathrm{ml}$ of Tween 80 to $5.0 \mathrm{ml}$ volumes of the cholesterol suspension in buffer. At this concentration Tween $\mathbf{8 0}$ did not affect either the erythrocyte or the streptolysin $O$.

\section{CHOLESTEROL-TREATED SERA}

Many of the experiments performed were done with a single batch of sterile horse serum, stored within a few hours of collection in $10 \cdot 0 \mathrm{ml}$ aliquots at $-20^{\circ}$. Preliminary tests showed that it had a very low titre of antistreptolysin $\mathrm{O}$ activity due to antibody $(<125)$. Cholesterol suspensions in buffer were added as described under Results.

\section{BOVINE SERUM ALBUMIN}

This was supplied as a $30 \%$ suspension (Sigma Chemicals). Suitable dilutions were prepared and treated with cholesterol as described under Results.

\section{SERA WITH RAISED CHOLESTEROL LEVELS}

Human sera with high total cholesterol levels were obtained from patients with essential hypercholesterolaemia and with the nephrotic syndrome. However, great difficulty was experienced in obtaining sera with levels in excess of $450 \mathrm{mg} \%$. To overcome this, rabbits were fed a cholesterol-rich diet by simply adding cholesterol powder to solid feed along with powdered cholic acid. After some three weeks venous blood was collected from the ear veins. Cholesterol levels were measured by the method of Levine and Zak (1964).

\section{PANCREATIN SOLUTION}

Pancreatin was used to split the esterified cholesterol fraction of serum. Solutions were prepared at $10 \%$ concentration in $2 \mathrm{~N}$ sodium carbonate by gentle heating to $56^{\circ} \mathrm{C}$.

DIGITONIN SOLUTION

Digitonin powder (Analar grade BDH) was dissolved in $50 \%$ ethyl alcohol. Since digitonin is haemolytic preliminary experiments were done to find a suitable concentration which would precipitate the protein-bound non-esterified cholesterol fraction of serum without causing haemolysis of erythrocytes added subsequently. This corresponded to $0.08 \mathrm{ml}$ of a $2.5 \%$ solution in $50 \%$ alcohol added to $2.0 \mathrm{ml}$ volumes of serum together with $0.01 \mathrm{ml}$ of $10 \%$ acetic acid.

\section{Results}

EFFECT OF PHYSICAL STATE OF CHOLESTEROL

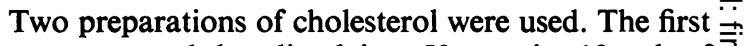
was prepared by dissolving $50 \mathrm{mg}$ in $10 \mathrm{ml}$ of $\stackrel{\overrightarrow{9}}{\stackrel{9}{+}}$ absolute ethanol followed by dilution in buffer with $\bar{C}$ Tween 80 as described. The second was made from $\overline{\underline{D}}$. the same batch of cholesterol with $50 \mathrm{mg}$ added to $\frac{\overline{\bar{p}}}{\bar{\phi}}$ $10 \mathrm{ml}$ of buffer and shaken vigorously to obtain $\stackrel{\mathbb{\Omega}}{\Omega}$ maximal dispersion. Serial dilutions in buffer were made in the same way. In these latter tubes most of $\vec{\omega}$

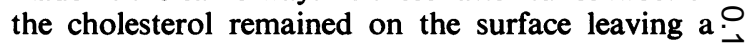
relatively clear layer beneath. Streptolysin $O$ and red $\vec{\omega}$ cells were then added as described. The $50 \%$ haemolytic endpoints are shown in Table I.

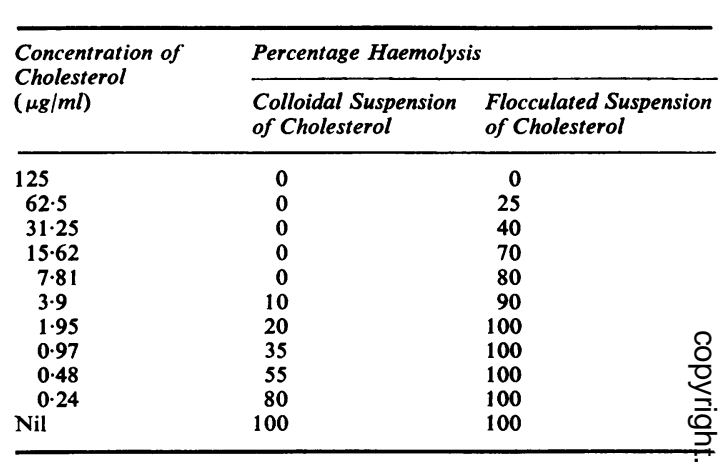

Table I Effect of physical state of cholesterol on streptolysin $O$ activity

The results show that free cholesterol in dispersed colloidal form could be detected by its antistreptolysin effect at a concentration of approximately $0.4 \mu \mathrm{g} / \mathrm{ml}$. A series of such investigations consistently gave values for $50 \%$ haemolysis corresponding to cholesterol levels of between 0.4 and $1.0 \mu \mathrm{g} / \mathrm{ml}$. This 3 . compares with a level of about 25 to $30 \mu \mathrm{g} / \mathrm{ml}$ where the cholesterol was in a less dispersed physical state. In these studies it was essential to use separate pipettes for each dilution. Where the same pipette was used a marked 'tailing' effect on the $50 \%$ endpoint was observed due to the tendency of the cholesterol to adhere to the sides of the pipette. N EFFECT OF HIGH SERUM CHOLESTEROL LEVELS N
ON STREPTOLYSIN O ACTIVITY

Antistreptolysin activity was measured as described $\widetilde{\sigma}$ in a number of human and rabbit sera with raised $\stackrel{\circ}{C}$ total cholesterol levels. Results are shown in Table II.

In none of the human sera tested was there a rise of antistreptolysin $O$ activity associated with raised total cholesterol levels at least as far as $450 \mathrm{mg}$. 


\begin{tabular}{ccc}
\hline Sera & $\begin{array}{l}\text { Total Cholesterol } \\
\text { Level } \\
(\mathbf{m g} \%)\end{array}$ & $\begin{array}{l}\text { Serum Antistreptolysin } \\
\text { Level } \\
\text { (Todd units) }\end{array}$ \\
\hline 1 Human & 334 & $<125$ \\
2 Human & 336 & $<125$ \\
3 Human & 344 & 166 \\
4 Human & 400 & $<125$ \\
5 Human & 450 & $<125$ \\
6 Human & 450 & 125 \\
7a Rabbit & 40 & $<125$ \\
7b Rabbit & 90 & $<125$ \\
8a Rabbit & 45 & $<125$ \\
8b Rabbit & 215 & 500 \\
9a Rabbit & 40 & 2500 \\
9b Rabbit & 390 & $<125$ \\
10a Rabbit & 30 & 833 \\
10b Rabbit & 175 & \\
\hline
\end{tabular}

Table II Serum cholesterol and antistreptolysin activity

$7 \mathrm{a}, 8 \mathrm{a}, 9 \mathrm{a}, 10 \mathrm{a}$ : before cholesterol diet.

$7 \mathrm{~b}, 8 \mathrm{~b}, 9 \mathrm{~b}, 10 \mathrm{~b}$ : after cholesterol diet.

However, three of the four rabbits fed cholesterol had significantly raised antistreptolysin activity. The mean serum cholesterol level in the normal rabbit is about $45 \pm 18 \mathrm{mg} \%$ as compared with $181 \pm$ $22 \mathrm{mg} \%$ in human sera. In addition about $50 \%$ of rabbit serum cholesterol is esterified as compared with about $33 \%$ in the human. The remaining fraction, often referred to as 'free' cholesterol, is in fact protein bound, mainly to lipoprotein moieties. Neither the esterified nor protein-bound fractions of normal sera are available to interfere with streptolysin $\mathbf{O}$ activity and raising total cholesterol in human serum two to three fold does not produce an antistreptolysin effect, presumably because the additional cholesterol is protein bound or esterified. Where the total cholesterol is raised fivefold or greater, as in the case of the rabbit sera in Table II, an antistreptolysin effect is apparent. In view of the high sensitivity of the method in detecting free cholesterol (between 0.4 and $1.0 \mu \mathrm{g} / \mathrm{ml}$ ) the findings suggest that there is a limit to the amount of cholesterol which can be esterified or will saturate lipoprotein binding sites and that beyond this some of the cholesterol exists in fact in true 'free' form.

EFFECT OF ADDING CHOLESTEROL TO NORMAL SERUM

Alcoholic cholesterol solutions containing varying amounts of cholesterol were added in $0.1 \mathrm{ml}$ amounts to $1.0 \mathrm{ml}$ volumes of sterile horse serum. The initial cholesterol level of the serum was 120 $\mathrm{mg} \%$. Antistreptolysin levels were then determined as before. Results are shown in Table III.

These results show that up to $400 \mu \mathrm{g}$ of cholesterol could be added to $1.0 \mathrm{ml}$ of horse serum without any antistreptolysin effect becoming manifest. This is

\begin{tabular}{|c|c|}
\hline $\begin{array}{l}\text { Cholesterol Added to } \\
1.0 \mathrm{ml} \text { of Serum }{ }^{1} \\
(\mu \mathrm{g})\end{array}$ & $\begin{array}{l}\text { Antistreptolysin } \\
\text { Activity } \\
\text { (Todd units) }\end{array}$ \\
\hline 1000 & 1280 \\
\hline 700 & 833 \\
\hline 600 & 500 \\
\hline 400 & $<125$ \\
\hline 200 & $<125$ \\
\hline 100 & $<125$ \\
\hline 1 & $<125$ \\
\hline
\end{tabular}

Table III Addition of cholesterol to normal horse serum

${ }^{1}$ Serum cholesterol level-120 mg \%.

approximately a $40 \%$ increase in the total amount of cholesterol. Beyond this level additional cholesterol can no longer be bound and is detectable by its antistreptolysin effect.

EFFECT OF PANCREATIN-TREATED SERA ON ANTISTREPTOLYSIN LEVELS

Pancreatin splits the ester linkage of bound cholesterol. It was therefore anticipated that sera with raised cholesterol levels, but which did not exhibit an increased antistreptolysin $\mathrm{O}$ effect, might do so if the ester moiety were split and if the cholesterol so released led to saturation of the lipoprotein fraction, which already contained an excess of cholesterol.

Pancreatin was dissolved in sodium carbonate as described. It was then added in $0.06 \mathrm{ml}$ amounts to replicate tubes containing $1.0 \mathrm{ml}$ amounts of human sera. Tubes were then incubated at $56^{\circ}$ for three hours. Serial dilutions were made, streptolysin $\mathbf{O}$ and cells were then added as before and the antistreptolysin effect was measured. The sera used in these experiments were the human sera with raised total cholesterol levels shown in Table II. Suitable control tubes with pancreatin and sodium carbonate were included. Results are shown in Table IV.

\begin{tabular}{llll}
\hline Sera & $\begin{array}{l}\text { Cholesterol } \\
\text { Level } \\
(m g \%)\end{array}$ & \begin{tabular}{l} 
Antistreptolysin \\
\cline { 3 - 4 }
\end{tabular} & $\begin{array}{l}\text { Activity (Todd units) } \\
\text { Before }\end{array}$ \\
\hline 1 & 450 & 125 & $\begin{array}{l}\text { After } \\
\text { Pancreatin }\end{array}$ \\
2 & 336 & $<125$ & 833 \\
3 & 334 & $<125$ & 833 \\
4 & 344 & 166 & 500 \\
5 & 450 & 125 & 500 \\
6 & 450 & 125 & 500 \\
\hline
\end{tabular}

Table IV Effect of pancreatin on antistreptolysin levels of human sera

Table IV shows that after pancreatin treatment of the sera there was a marked rise in antistreptolysin $O$ activity. No diminution of streptolysin $\mathbf{O}$ activity was noted with either sodium carbonate or pan- 
creatin and the antistreptolysin $O$ effect appears to be due to the liberation of free cholesterol, unable to be bound by lipoproteins.

REMOVAL OF PROTEIN-BOUND CHOLESTEROL WITH DIGITONIN

Digitonin solution was added to pools of sera from rabbits fed cholesterol (antistreptolysin $O$ levels of 2500), as described under Methods. After mixing gently the tubes were kept at $4.0^{\circ}$ for 72 hours. After centrifuging the supernatant fluids were removed from any precipitate which formed. The alcohol was then driven off by gentle heat at $55^{\circ}$ in a water bath under vacuum. Streptolysin $O$ and cells were added in the usual way and the antistreptolysin $\mathbf{O}$ activity remaining was determined. Results are detailed in Table V.

\begin{tabular}{|c|c|c|c|}
\hline \multirow[t]{2}{*}{ Pooled Sera } & \multirow{2}{*}{$\begin{array}{l}\text { Cholesterol } \\
\text { Level } \\
(m g \%)\end{array}$} & \multicolumn{2}{|c|}{ Antistreptolysin Titre } \\
\hline & & $\begin{array}{l}\text { Before } \\
\text { Digitonin }\end{array}$ & $\begin{array}{l}\text { After } \\
\text { Digitonin }\end{array}$ \\
\hline $\begin{array}{l}1 \\
2\end{array}$ & $\begin{array}{l}390 \\
215\end{array}$ & $\begin{array}{l}2500 \\
2500\end{array}$ & $\begin{array}{l}125 \\
125\end{array}$ \\
\hline
\end{tabular}

Table V Antistreptolysin levels of rabbit sera after removal of non-esterified cholesterol with digitonin

Table $\mathrm{V}$ indicates clearly that removal of the nonesterified cholesterol fraction abolished the antistreptolysin activity of the sera. Since these pooled sera had raised antistreptolysin levels $(2500)$ due to cholesterol, it is likely that the non-esterified fraction consists of lipoprotein-bound cholesterol and a true 'free' cholesterol unable to bind because of saturation of lipoprotein sites.

EFFECT OF BOVINE ALBUMIN ON INTERACTION OF CHOLESTEROL WITH STREPTOLYSIN O

Lipoproteins constitute the main transporters of non-esterified cholesterol in serum. Specifically, serum albumin does not appear to play any part in cholesterol binding as shown by conventional chemical methods. However, in view of the sensitivity of the present method in detecting free cholesterol experiments were carried out to determine the effect of adding serum albumin to cholesterol and streptolysin.

Cholesterol in $1.0 \%$ alcoholic solution containing $6000 \mu \mathrm{g} / \mathrm{ml}$ was added in $0.4 \mathrm{ml}(2400 \mu \mathrm{g})$ amounts to $0.6 \mathrm{ml}$ volumes of varying concentrations of bovine serum albumin. After standing at room temperature for two hours, serial dilutions were prepared. Streptolysin was added and antistreptolysin activity detected as before.

Results are shown in Figure 1.

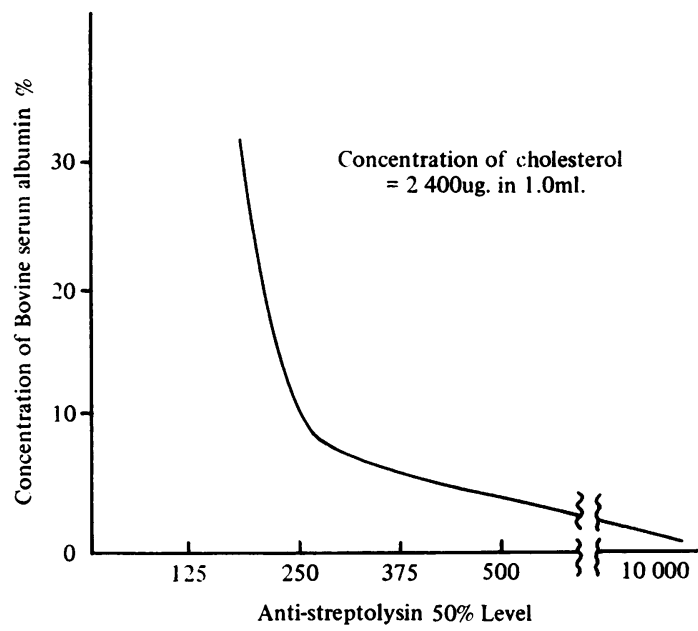

Fig. Effect of bovine albumin on interaction of cholesterol with streptolysin $O$.

The Figure shows that increasing the concentra $\frac{0}{0}$ tion of bovine serum albumin reduced the anti streptolysin activity of the cholesterol. This was further investigated by varying the method of addi- N tion of the reagents as follows. An alcoholic solution of cholesterol containing $60 \mu \mathrm{g} / \mathrm{ml}$ was diluted ASO buffer in $1.1 \mathrm{ml}$ amounts in 3 in. $\times \frac{1}{2}$ in. tubes (dilution series, $-12,50,100,125,166,250$, and, 333). Four replicate sets of tubes were prepared. Toᄋ each tube of set 1 was added $0.25 \mathrm{ml}$ of a 4.0 unit $/ \mathrm{mP}$ solution of streptolysin $O$ and after 10 minutes a $\vec{\sigma}$ room temperature a further $0.25 \mathrm{ml}$ of buffer solu 3 tion was added. To set 2 was added $0.25 \mathrm{ml}$ of $5.0 \%$ bovine serum albumin and after 10 minutes at room. temperature $0.25 \mathrm{ml}$ of streptolysin 0 . Set 3 was similar to set 2 except that the streptolysin $O$ was added first and the bovine serum albumin solution. after 10 minutes. To set 4 was added $0.5 \mathrm{ml}$ of añ aliquot mixture of streptolysin $\mathrm{O}$ and bovine serum albumin mixed immediately before addition to the cholesterol. All tubes were then incubated for $\mathrm{a}^{\mathrm{P}}$ further 10 minutes at $37^{\circ}$. Cells were then added an 8 $50 \%$ haemolytic endpoints noted as before.

Identical endpoints were obtained for each set of tubes containing bovine serum albumin, ie, the sequence of addition of streptolysin $O$ and bovine serum albumin did not affect the reduced ability of the cholesterol to inhibit the streptolysin $O$ in the presence of bovine serum albumin.

There appear to be four possible reasons for the albumin effect. (1) Albumin might combine with cholesterol and prevent it from conbining with streptolysin $\mathrm{O}$. However, when ${ }^{14} \mathrm{Clabelled}$ cholestero 
was added to the serum albumin used in the present experiments and then subjected to electrophoresis on cellulose acetate all radioactivity was located at the point of origin and none was present in the albumin region. (2) Albumin might combine directly with the erythrocyte membrane and increase its sensitivity to the effect of streptolysin $\mathrm{O}$. However, treatment of red cells with varying concentrations of albumin from $1.0 \%$ to $30.0 \%$ for periods up to 18 hours did not alter the $50 \%$ haemolytic dose of streptolysin $\mathrm{O}$. (3) Albumin might combine with streptolysin $\mathrm{O}$ and increase its haemolytic activity, but again concentrations of albumin from $1.0 \%$ to $30.0 \%$ added to streptolysin $\mathrm{O}$ did not affect $50 \%$ haemolytic endpoints. (4) Albumin may combine with streptolysin $O$ by some form of protein-protein interaction, possibly involving Van der Waal's forces, at a site on the streptolysin $\mathrm{O}$ molecule distant from either the site for fixation to the erythrocyte or the additional site shown to be responsible for haemolysis. Such combination might then exert a steric hindrance effect on the attachment of cholesterol to the membrane fixation site of the streptolysin $\mathrm{O}$ molecule. This last hypothesis is supported by the results obtained by adding varying concentrations of bovine serum albumin to a standard amount of streptolysin $\mathrm{O}(40 \mathrm{I}-\mathrm{U} / \mathrm{ml})$. Albumin itself moved with a mobility almost identical to that of streptolysin $O$. The mobility of the streptolysin $\mathrm{O}$ progressively decreased with increasing concentrations of bovine serum albumin, indicating complex formation.

EFFECT OF PANCREATIN ON ANTISTREPTOLYSIN ACTIVITY OF BOVINE SERUM ALBUMINCHOLESTEROL MIXTURES

A series of Universal containers was prepared containing reagents as set out in the left hand portion of Table VI. They were then incubated in a water bath at $56^{\circ}$ for three hours. Serial dilutions in buffer were then made in $1.0 \mathrm{ml}$ amounts in 3 in. $\times \frac{1}{2}$ in. tubes for each container. Streptolysin $O$ and red cells were added and the tubes incubated as before.
The $50 \%$ haemolytic endpoints are shown in the right hand side of the table.

Neither pancreatin nor bovine serum albumin affected streptolysin $\mathbf{O}$ activity at the concentrations used. However, the interaction between bovine serum albumin and streptolysin $O$ is prevented by pancreatin allowing cholesterol to exert its antistreptolysin effect on the streptolysin $\mathbf{O}$.

\section{Discussion}

Streptolysin is capable of attaching to lipoprotein membranes of erythrocytes and other cells including leucocytes, macrophages, heart muscle cells, and chick embryo cells. In this respect it resembles other oxygen labile haemolysins, eg, pneumolysin, tetanolysin, and listeriolysin. Reduced streptolysin $O$ has been shown by Alouf and Raynaud (1968) to possess two biologically active sites: the (f) or fixation site attaches the streptolysin $\mathrm{O}$ molecule to cholesterol in the external lipoprotein layer of the erythrocyte membrane. Oxidized streptolysin $\mathrm{O}$ fails to attach. Binding appears to be thiol dependent and the disulphide bonds so formed are readily disrupted by sulphydryl agents. The second site $(t)$ is concerned with disruption of the cell membrane and release of haemoglobin. Whereas the binding stage is rapid and temperature independent, lysis is much slower and temperature dependent, being maximal at $37.0^{\circ} \mathrm{C}$ and almost absent at $4.0^{\circ} \mathrm{C}$. Approximately 360 molecules of streptolysin $\mathrm{O}$ are required to lyse a single cell. The (f) site which appears to comprise two cysteine residues is blocked by oxidation, thiolbinding agents, and cholesterol. However cholesterol does not affect a stronial-bound streptolysin $O$. The activity of cholesterol appears to be dependent on possession of the beta-hydroxyl group at position 3 of the A ring and a hydrophobic side chain attached to position 17. The structural requirements of this side chain are at present under investigation in this laboratory.

Petersen, Nowak, Thiele, and Urbaschek (1966)

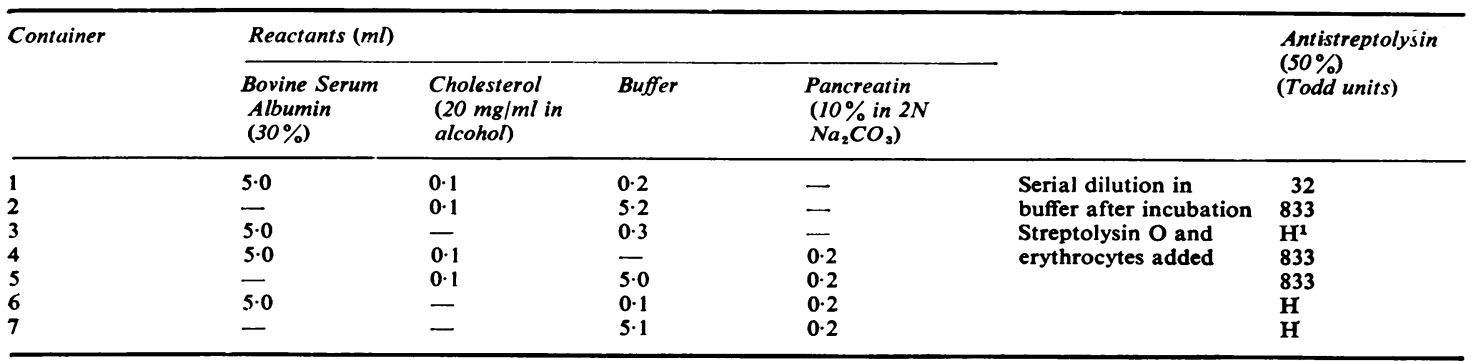

Table VI Effect of pancreatin on antistreptolysin activity of bovine serum albumin-cholesterol mixtures ${ }^{1} \mathbf{H}=$ Complete haemolysis in all tubes. 
have shown that delipidation of erythrocytes renders them unable to fix streptolysin $O$ and the lipid extracts are strongly inhibitory. Kavanau (1965) has also shown that cholesterol is a constituent of cell membranes other than erythrocytes but it is not clear whether the mechanism of combination with streptolysin $\mathbf{O}$ is identical to that of erythrocytes.

The present results confirm the extreme degree of sensitivity of reduced streptolysin $O$ to the inhibiting effect of free cholesterol, the method being capable of detecting less than $1000 \mathrm{ng} / \mathrm{ml}$. They also show that raised levels of cholesterol in human sera were not associated with raised antistreptolysin $\mathbf{O}$ activity of the sera, at least up to $450 \mathrm{mg} \%$, approximately two and a half times normal levels. However, in rabbits with levels of cholesterol some five times normal, increased antistreptolysin $O$ activity was demonstrated. It is suggestive that this represents a cholesterol serum fraction which is neither esterified nor combined to lipoproteins, possibly because of saturation of binding sites on the latter. These findings are similar to those of Stollerman (1954) who also showed that addition of heparin to serum from cholesterol-fed rabbits increased the antistreptolysin $\mathrm{O}$ effect. Horse serum appears less capable of binding added cholesterol since increased antistreptolysin $\mathrm{O}$ activity was noted when the concentration was increased from the base level of $1200 \mu \mathrm{g} / \mathrm{ml}$ to $1800 \mu \mathrm{g} / \mathrm{ml}$ a rise of only $50 \%$.

Treatment of human sera with raised total cholesterol levels with pancreatin released the esterified fraction resulting in a total concentration of non-esterified cholesterol sufficiently high to saturate lipoprotein-binding sites and leave 'free' cholesterol which showed an antistreptolysin $\mathrm{O}$ effect. Lecithinase derived from $\mathrm{Cl}$. welchii has a similar effect (Stollerman, 1954). Conversely, removal of non-esterified cholesterol with digitonin before treatment with pancreatin did not increase antistreptolysin $O$ activity of the serum since the cholesterol freed by splitting the ester linkage is presumably able to attach to available lipoprotein sites.

In the case of rabbits with raised antistreptolysin $O$ activity and high serum cholesterol levels precipitation of the non-esterified fraction with digitonin reduced antistreptolysin $O$ activity, again due to removal of what would appear to be a true 'free' cholesterol moiety. Badin and Barillec (1970) noted a similar effect of digitonin after removal of excess digitonin with transdehydroandrosterone.

The ability of bovine serum albumin to diminish the inhibiting effect of cholesterol is of interest. At first sight it was thought possible that a weak combination of bovine serum albumin with cholesterol might be taking place and was being detected in view of the high sensitivity of the method. However, the failure of ${ }^{14} \mathrm{C}$-labelled cholesterol to move electros phoretically with bovine serum albumin in mixtureso discounts this possibility, and evidence of complexing of bovine serum albumin and streptolysin $\mathrm{O}$ wass? obtained from cellulose acetate electrophoresis of mixtures of these. As shown in Table VI complexingo was prevented by the addition of pancreatin tos bovine serum albumin before addition of strepto- $\frac{\pi}{2}$ lysin $\mathbf{O}$. As already mentioned it appears likely that the combination of bovine serum albumin and streptolysin $O$ sterically prevents attachment of cholesterol to the latter.

The effect of bacterial contamination of sera ino producing false high levels of antistreptolysin og activity has not been fully investigated. Preliminary studies in this laboratory suggest that two mechan- isms might be involved, either a direct proteolytico effect on streptolysin $O$ or release of enzymeso capable of splitting the esterified cholesterol fraction? and raising the non-esterified fraction to a leveP higher than is capable of being bound to lipoprotein $\vec{p}$ sites. The latter mechanism is undoubtedly involved? as far as $\mathrm{Cl}$. welchii is concerned. Early studieso suggest that Pseudomonas strains are especially믐 capable of producing this effect but the mechanisme is not clear.

False positive antistreptolysin results are not like्gy to be a problem with most human sera with raisedo cholesterol values. However it is known that high antistreptolysin values may be found in cholestatice liver disease (Badin, Cabau, Lévy, and Cachin, 1962) and nephrosis (Stollerman, 1954). Badin and $\mathbb{R}$ Barillec (1970) have shown that these may be dis $\overrightarrow{\overrightarrow{0}}$ tinguished from true antibody-mediated antistrepto 3 lysin activity since digitonin will remove that activity in the former case but has no effect on antistrepto? lysin levels due to immunoglobulins.

We are indebted to Dr D. Horn, Department o Clinical Chemistry, Western General Hospital, for the electrophoretic analysis of streptolysin-albuming mixtures.

\section{References}

Alouf, J. E., and Raynaud, M. (1968). Some aspects of the mechanisniof lysis of rabbit erythrocytes by streptolysin O. In Curren? Research on Group A Streptococcus, edited by R. Caravano, pp. 192-206. Excerpta Medica Foundation, Amsterdam.

Badin, J., and Barillec, A. (1970). Streptolysin $O$ inhibition by serun? gamma-G-globulin and beta-lipoprotein after blocking of

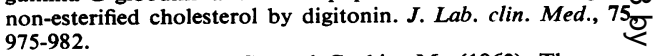

Badin, J., Cabau, N., Lévy, C., and Cachin, M. (1962). The nome specific inhibition of Streptolysin $O$ in liver diseases. It significance and clinical value. (French). Ann. Biol. clin., 20
$525-541$.

Hewitt, L. F., and Todd, E. W. (1939). The effect of cholesterol ando of sera contaminated with bacteria on the haemolysins pro $\overline{0}$ duced by haemolytic streptococci. J. Path. Bact., 49, 45-51. 
Kavanau, J. L. (1965). Structure and Function in Biological Membranes, vol. 1, p. 132. Holden-Day, San Francisco.

Levine, J. B., and Zak, B. (1964). Automated determination of serum total cholesterol. Clin. chim. Acta, 10, 381-384.

Petersen, K. F., Nowak, P., Thiele, O. W., and Urbaschek, B. (1966). Investigations concerning the action of streptolysin $O$ and its unspecific inhibition by lipids. Int. Arch. Allergy, 29, 69-81.

Rantz, L. A., and Randall, E. (1945). A modification of the technic for determination of the antistreptolysin titer. Proc. Soc. exp. Biol. (N.Y.), 59, 22-25.

Stollerman, G. H. (1954). The use of haemolysin inhibition in the study of experimental and clinical hyperlipemia; the nonspecific inhibition of streptolysin $O$ by serum lipoproteins. $J$. clin. Invest., 33, 1233-1241.

Watson. K. C., Rose, T. P., and Kerr, E. J. C. (1971). Unpublished observations.

\section{The September 1972 Issue}

\section{THE SEPTEMBER 1972 ISSUE CONTAINS THE FOLLOWING PAPERS}

A clinical and experimental study of platelet function in chronic renal failure E. P. EVANS, R. A. BRANCH, AND A. L. BLOOM

Detection of fibrinogen-fibrin degradation products by counterelectrophoresis JEROME I. BRODY

A comparison of the TRCII and latex-particle tests for the titration of FR-antigen C. L. AROCHAPIÑANGO

A stable haemagglutinating antigen for detecting toxoplasma antibodies $\mathrm{H}$. THORNBURN AND $\mathrm{H}$. WILLIAMS

Variations in interferon production by lymphocytes from patients with chronic lymphatic leukaemia A. M. R. MACKENZIE

An example of anti-s causing mild haemolytic disease of the newborn M. J. DAVIE, D. S. SMITH, URSULA M. WHITE, AND D. DYBALL

Radioimmunoassay of human growth hormone: technique and application to plasma, cerebrospinal fluid, and pituitary extracts FRANCES J. THOMAS, H. M. LLOYD, AND M. J. THOMAS

An evaluation of the Monosticon rapid slide test for the diagnosis of infectious mononucleosis G. L. SCOTT AND C. J. PRIEST

The rapid plasma reagin (circle) card test in biological false positive and leprosy sera M. F. GARNER AND J. L. BACKHOUSE

Serum protein levels in primary biliary cirrhosis R. N. M. MaCSWEEN, C. H. W. HORNE, ANNE J. MOFFAT, AND HAZEL M. HUGHES
Foetus in foetu: serological assessment of monozygotic origin by automated analysis M. J. BOYCE, J. W. LOCKYER, AND C. B. S. WOOD

The erythrasma microorganism in situ: studies using the skin surface biopsy technique R. MARKS, N. D. RAMNARAIN, B. BHOGAL, AND N. T. MOORE

Congenital dilatation of the intrahepatic bile ducts with cholangiocarcinoma P. J. GALLAGHER, R. R. MILLIS, AND M. J. MITCHINSON

Mucosal metaplasia in the appendix J. B. MacGILLIVRAY

Granuloma venereum S. B. BHAGWANDEEN AND Y. A. MOTTIAR

A histological analysis of granulomatous hepatitis M. HUGHES AND H. FOX

Light and electron microscopy of globular hyaline inclusions in liver cells J. C. E. UNDERWOOD

The teaching of chemical pathology to medical students in the United Kingdom D. N. BARON AND ANGELA FAIRNEY

\section{Technical methods}

An immunological method for the detection and estimation of fetal haemoglobin J. KOHN AND B. V. PAYNE

Differential staining of neuronal and glial nuclei SERGE DUCKETT

Improved sensitivity of the electrophoresis method by tannic acid for detection of Australia antigen R. HOPKINS AND P. C. DAS

Letters to the Editor

Book reviews

Copies are still available and may be obtained from the PUBLISHING MANAGER, BRITISH MEDICAL ASSOCIATION, TAVISTOCK SQUARE, LONDON, WC1H 9JR, price $£ 1.05$ 